\title{
SURFACE QUALITY FINISH IN LASER CUTTING USING TAGUCHI DESIGN
}

\author{
Vinay Sharma, Somnath Chattopadhyaya, Sergej Hloch
}

Original scientific paper

The present work aims at obtaining parametric combination to achieve the best surface finish and assess effects of selected process parameters on a laser cut quality for laser cutting. This helps to study the variation in response parameter ( $R a$ value) for various levels of selected process parameters. In the present work mild steel specimen is used and the effect of the key parameters such as laser pulse frequency (pulse repetition rate), laser pulse width and cutting speed on surface finish are critically analysed. For experimental design and parametric analysis robust design is used i.e. a fractional factorial experimental design with an appropriate orthogonal array followed by variance and sound to noise ratio analysis.

Keywords: cutting speed; factorial design; laser pulse width; orthogonal array; pulse repetition rate (PRR) or pulse frequency

Kvaliteta završne obrade kod laserskog rezanja uporabom Taguchi dizajna

Izvorni znanstveni članak

Cilj je ovoga rada dobivanje parametrijske kombinacije kako bi se postigla najbolja završna obrada i procijenili učinci odabranih parametara obrade na kvalitetu laserskog rezanja kod uporabe lasera. To pomaže kod proučavanja promjena u parametru reakcije (vrijednost $R a$ ) za različite razine odabranih parametara procesa. U ovom radu korišten je uzorak mekog čelika i kritički je analiziran učinak ključnih parametara kao što su frekvencija laserskog impulsa (brzina ponavljanja impulsa), širina impulsa i brzina rezanja na završnu obradu. Za plan pokusa i analizu parametara rabljen je robusni dizajn tj. frakcijski faktorski plan pokusa s prikladnim ortogonalnim nizom nastavljenim analizom varijance i odnosa zvuka i šuma.

Ključne riječi: brzina ponavljanja impulsa (PRR) ili frekvencija impulsa; brzina rezanja; faktorski plan pokusa; ortogonalni niz; širina impulsa lasera

\section{Introduction}

Unconventional technologies [1] such as Electrical discharge machining (EDM) $[2,3]$, Water Jet machining $[4 \div 6]$; plasma machining $[7,8]$ and laser machining [9] are one of the most extensively used non-conventional material removal processes. Laser is used to cut a wide range of materials. It is suitable for cutting thin workpieces. $\mathrm{CO}_{2}$ laser and $\mathrm{Nd}$ :YAG laser are the most popular lasers in cutting, they can provide high peak powers (above $1 \mathrm{~kW}$ ) for high-speed cutting. Laser cutting can be basically divided into two kinds $[10,11]$. First is the direct evaporative laser cutting, in which laser provides the latent heat until the material reaches vaporization point and ablate in vapour state, such as laser cutting of organic materials - paper, cloth or polymers. Such materials have poor thermal conductivity; a non-reactive gas jet may be used to reduce charring. The second is laser cutting through melting or fusion, laser energy melts the target material and the assist gas jet blows the molten material away [10]. In this way the requirement of laser energy is lower compared with vaporization cutting [11]. The assist gas jet can be reactive or non-reactive. If the assist gas jet is reactive, laser heat combined with exothermic chemical reaction with the assisting gas provides the heat necessary for melting \& vaporization of the target material. This is called reactive laser cutting. This helps to further reduction of the necessary laser energy. Although good number of fundamental research has been done in the area of laser cutting technology $[12 \div 15]$ still further research is required to determine the combine effects of the process parameters for achieving high quality surface finish and dimensional accuracy. This will also help to develop knowledge based system and effective utilization of the process parameters for the desired results. Present work focuses on obtaining parametric combination to achieve the best surface finish and assess effects of various process parameters. Experiments were conducted on a Mild Steel specimen of thickness $0,65 \mathrm{~mm}$ by changing the process parameters (pulse frequency, pulse repetition rate and cutting speed) on a laser cut quality with pulsed beam Nd:YAG laser and the $R a$ value (response parameter) was observed. For this fractional factorial design (orthogonal array) was employed as a scientific approach for planning experiment followed by variance and signal to noise ratio analysis.

\section{Taguchi method}

The concept of Robust Engineering is based on the principles of Taguchi Methods used in many works dealing with (un)conventional technologies for prediction of output surface profile parameters $[16 \div 26]$. Genichi Taguchi [29] derived these principles after several years of research. The concept evolved systematically in 1950's. These principles are aimed at providing the companies a cost effective methodology to enhance their competitive position in the global market. Among the various approaches used the most frequently used approach to design a test is a full factorial experiment [17]. However, for full factorial experiments, there are $n_{\mathrm{f}}$ possible combination that must be tested where $n$ is the levels and $\mathrm{f}$ is the number of factors. Therefore, it is very time-consuming when there are many factors at many levels $[26 \div 28]$. Taguchi methods were developed in Japan by Genichi Taguchi to improve the implementation of total quality control in Japan [29]. They are based on the design of experiments to provide near optimal quality characteristics for a specific objective. The real power of Taguchi methods comes from their simplicity of implementation. The goal is not just to optimize an arbitrary objective function, but also to reduce the sensitivity of engineering designs to uncontrollable factors or noise [16, 23, 24]. Taguchi methods are also called robust design in the USA. In the traditional 
experimentation strategy, one supposes that the factors, on which we act, are perfectly controlled and that their values remain constant throughout the experiment. The factors not included in the study are supposed not to vary. This concept is however too theoretical because one is never certain that these factors will remain constant indeed. To avoid the bias caused by these uncontrollable factors, the traditional experimental strategy consists of making the experiments in a random order. The effects of uncontrollable factors are then included in the experimental results dispersion. Thus one often seeks to eliminate all the possible variation sources, which is unfortunately often impossible in practice. Taguchi, on the other hand, considers that rather than to eliminate the causes from the variations, it is preferable to analyse them and to find experimental conditions for which these causes have a minimum effect. Thus, instead of seeking to eliminate the causes of variations (called noises by Taguchi), he proposes to minimize their influence. The factors are divided into two categories: the factors relating to the system on which one can easily act (called controllable factors) and the factors (called noise factors) whose possible variations are not (or with difficulty) controllable and can generate a degradation of the system characteristics. The major steps of implementing the Taguchi method are: (1) to identify the factors/interactions, (2) to identify the levels of each factor, (3) to select an appropriate orthogonal array (OA), (4) to assign the factors/interactions to columns of the $\mathrm{OA},(5)$ to conduct the experiments, and (6) to analyse the data and determine the optimal levels. This work uses L9, three-level matrix for an initial experiment, where the numbers 0,1 and 2 stand for the levels of the factors. In data analysis, signal-to-noise $(\mathrm{S} / \mathrm{N})$ ratios are used to allow the control of the response as well as to reduce the variability about the response. The use of ANOVA (analysis of variance) is to calculate the statistical confidence associated with the conclusions drawn

\section{Experimental conditions of experiment}

A CNC controlled SI Laser SLP200 Nd: YAG laser with three-axis control (Fig. 1) was used for cutting.

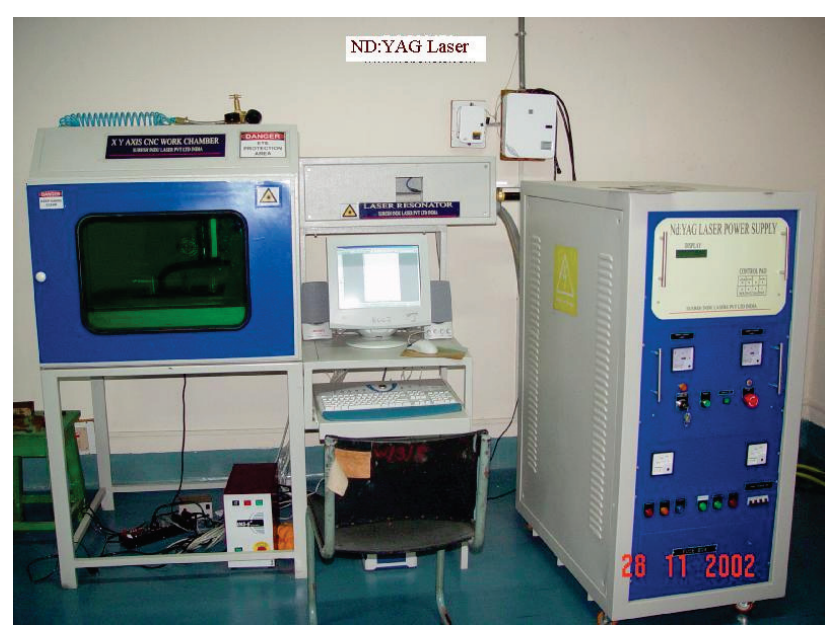

Figure 1 Photograph of the ND:YAG laser

The machine basically consists of a laser resonator and beam delivery unit, power supply unit, cooling unit and $\mathrm{CNC}$ controller for $X, Y$ and $Z$-axis movement. The specifications of the machine are given in Tab. 1. The material used for laser cutting was mild steel (carbon $0,1 \div$ $0,25 \%$ ) of thickness $0,65 \mathrm{~mm}$ with the assisting gas as Oxygen at a pressure of $3,5 \mathrm{kgf} / \mathrm{cm}^{2}$ (to nozzle) For measuring the surface roughness of samples of thickness $b=0,65 \mathrm{~mm}$ a mounting fixture was developed consisting of five slots for holding the samples cut by the laser process. (Fig. 2). The surface roughness $(R a)$ measurements of the work pieces was done using TaylorHobson Surtronic machine provided by Taylor-Hobson. The measuring range of the instrument varies from the 0,01 to $150 \mu \mathrm{m}$ with an accuracy of $2 \%$.

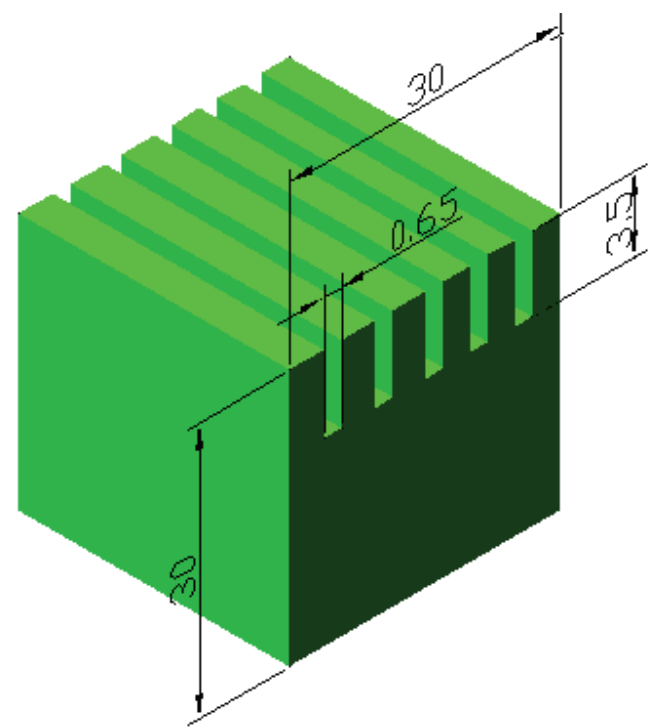

Figure 2 Holding fixture

Table 1 Technical specification of the machine

\begin{tabular}{|l|c|}
\hline \multicolumn{1}{|c|}{ Model } & SLP-200 \\
\hline Average power & $200 \mathrm{~W}$ \\
\hline Pulse energy @20 ms & $50 \mathrm{~J}$ \\
\hline Peak power & $7 \mathrm{~kW}$ \\
\hline Pulse width range & $0,3 \div 20 \mathrm{~ms}$ \\
\hline Pulse repetition rate & $450 \times 600 \times 150 \mathrm{~mm}$ \\
\hline Work table size & 3 PHASE 440VAC 20 AMPS \\
\hline Power requirements & chilled water with external cooling \\
\hline Cooling method &
\end{tabular}

\section{The results measured during the experiment}

The basic objective of the experimentation was to obtain parametric combination to achieve the best surface finish ( $R a$ value) and assess effects of various process parameters on $R a$ value. Therefore laser pulse width, pulse repetition rate and cutting speed were taken as the key parameters identified to be the most influencing in controlling the response parameter ( $R a$ value). The experiments were carried out in two stages. Initially, different parameters were varied individually keeping others at a value which yields better results. Accordingly a continuous range of each parameter was established which resulted in best values of selected quality parameter $R a$ value (response parameter in Taguchi robust design terminology). Keeping these ranges of various processes parameters (control factors/parameters in Taguchi robust design terminology); the parameters were varied individually so as to attain information regarding the 
particular parameter. For all the experiments all other process parameters including the gas pressure and nozzle height were kept constant. The range of pulse width for best cutting is from 2 to $25 \mathrm{~ms}$; for pulse repetition rate it is from $20 \mathrm{~Hz}$ to 30 and cutting speed ranges from 1 to 3 $\mathrm{mm} / \mathrm{s}$ for the sheet thickness $0,65 \mathrm{~mm}$. The surface roughness measurements of the work pieces were done using Taylor-Hobson Surtronic machine. The range of above-mentioned control parameters was divided into three levels, each as shown in Tab. 2. For each control parameter 0 indicates a level with low value, 1 indicates medium and 2 indicates high value. For such three factor three level experiments the suitable orthogonal array (i.e. L9(3)4 orthogonal array) (Tab. 3) was selected. Orthogonal array (O.A.) facilitates statistical analysis of influence of individual control factors \& their interaction. Three-factor O.A. saves lot of experimentation as in case of varying one factor at a time. Robust design is an engineering methodology for optimizing the product and process conditions which are minimally sensitive to the various causes of variation and which produce highquality products with low development and manufacturing costs. Taguchi's parameter design is an important tool for robust design. Taguchi's tolerance design can also be classified as a robust design. In a narrow sense robust design is identical to parameter design, but in a wider sense parameter design is a subset of robust design. This work tries to obtain the best parametric combination for quality surface finish $(R a$ value) with two Robust Design tools like $\mathrm{S} / \mathrm{N}$ ratio analysis and orthogonal array and subsequent variance analysis. Experiments resulting from the orthogonal array (Tab. 3) were carried out with all other process parameters kept unchanged.

Table 2 Various factors and their levels

\begin{tabular}{|c|c|c|c|c|c|c|c|}
\hline \multicolumn{3}{|c|}{ A (Cutting speed mm/s) } & \multicolumn{3}{c|}{ B (Pulse width ms) } & \multicolumn{3}{c|}{ C (Pulse freq./Pulse repetition rate Hz) } \\
\hline $\mathrm{A}_{0}$ & $\mathrm{~A}_{1}$ & $\mathrm{~A}_{2}$ & $\mathrm{~B}_{0}$ & $\mathrm{~B}_{1}$ & $\mathrm{~B}_{2}$ & $\mathrm{C}_{0}$ & $\mathrm{C}_{2}$ \\
\hline $1 \mathrm{~mm} / \mathrm{s}$ & $2 \mathrm{~mm} / \mathrm{s}$ & $3 \mathrm{~mm} / \mathrm{s}$ & $1,5 \mathrm{~ms}$ & $2 \mathrm{~ms}$ & $3,9 \mathrm{~ms}$ & $10 \mathrm{~Hz}$ & $15 \mathrm{~Hz}$ \\
$20 \mathrm{~Hz}$ \\
\hline
\end{tabular}

Table 3 Orthogonal array [L9(3)4 ] and resulting experiments

\begin{tabular}{|c|c|c|c|c|c|c|c|}
\hline \multirow{2}{*}{ Experiment No. } & \multicolumn{4}{|c|}{ Column No. } & \multirow{2}{*}{ Condition } & \multirow{2}{*}{$\begin{array}{c}\text { Exp. Data } \\
R a_{\mathrm{Avg}}=R a_{1}+R a_{2}+R a_{3}\end{array}$} & \multirow{2}{*}{$\mathrm{S} / \mathrm{N}$ ratio $(\mathrm{db})$} \\
\hline & 1 & 2 & 3 & 4 & & & \\
\hline 1 & 0 & 0 & 0 & 0 & $\mathrm{~A}_{0} \mathrm{~B}_{0} \mathrm{C}_{0}$ & 131 & $-42,41873$ \\
\hline 2 & 0 & 1 & 1 & 1 & $\mathrm{~A}_{0} \mathrm{~B}_{1} \mathrm{C}_{1}$ & 115 & $-41,80272$ \\
\hline 3 & 0 & 2 & 2 & 2 & $\mathrm{~A}_{0} \mathrm{~B}_{2} \mathrm{C}_{2}$ & 100 & $-40,00000$ \\
\hline 4 & 1 & 0 & 1 & 2 & $\mathrm{~A}_{1} \mathrm{~B}_{0} \mathrm{C}_{2}$ & 122 & $-43,16461$ \\
\hline 5 & 1 & 1 & 2 & 0 & $\mathrm{~A}_{1} \mathrm{~B}_{1} \mathrm{C}_{0}$ & 225 & $-47,33265$ \\
\hline 6 & 1 & 2 & 0 & 1 & $\mathrm{~A}_{1} \mathrm{~B}_{2} \mathrm{C}_{1}$ & 146 & $-43,33027$ \\
\hline 7 & 2 & 0 & 2 & 1 & $\mathrm{~A}_{2} \mathrm{~B}_{0} \mathrm{C}_{1}$ & 157 & $-43,91187$ \\
\hline 8 & 2 & 1 & 0 & 2 & $\mathrm{~A}_{2} \mathrm{~B}_{1} \mathrm{C}_{2}$ & 180 & $-45,10545$ \\
\hline 9 & 2 & 2 & 1 & 0 & $\mathrm{~A}_{2} \mathrm{~B}_{2} \mathrm{C}_{0}$ & 256 & $-48,16480$ \\
\hline Basic mark & $\mathrm{a}$ & $\mathrm{B}$ & $a b$ & $\mathrm{ab} 2$ & & Total $\rightarrow$ & $-395,2311$ \\
\hline Assignment & A & $\mathrm{B}$ & $\mathrm{e}$ & $\mathrm{C}$ & & Avg. $\rightarrow$ & $-43,91457$ \\
\hline
\end{tabular}

Table 4 Effect of factors at various levels

\begin{tabular}{|c|c|c|c|}
\hline $\begin{array}{l}\text { Levels } \rightarrow \\
\text { Factors } \downarrow\end{array}$ & 0 & 1 & 2 \\
\hline $\mathrm{A}$ & $\underline{2,50742^{*}}$ & $-0,69461$ & $-1,81803$ \\
\hline $\mathrm{B}$ & $\underline{0,7495}{ }^{*}$ & $-0,83237$ & 0,08288 \\
\hline $\mathrm{C}$ & $-2,057603$ & 0,89882 & $\underline{1,15788} *$ \\
\hline
\end{tabular}

Table 5 Computation of variation for L9 (3)4 O.A.

\begin{tabular}{|c|c|c|c|c|c|c|c|c|c|c|c|c|c|}
\hline & Source & \multicolumn{3}{|c|}{$\mathrm{A}$} & \multicolumn{3}{|c|}{ B } & \multicolumn{3}{|c|}{$E$} & \multicolumn{3}{|c|}{$\mathrm{C}$} \\
\hline & Level & 0 & 1 & 2 & 0 & 1 & 2 & 0 & 1 & 2 & 0 & 1 & 2 \\
\hline & \multirow{3}{*}{ Data } & 131 & 122 & 157 & 131 & 115 & 100 & 131 & 115 & 100 & 131 & 115 & 100 \\
\hline & & 115 & 225 & 180 & 122 & 225 & 146 & 146 & 122 & 225 & 225 & 146 & 122 \\
\hline & & 100 & 146 & 256 & 157 & 180 & 256 & 180 & 256 & 157 & 256 & 157 & 180 \\
\hline 1 & Level sum & $346 *$ & 493 & 593 & $410 *$ & 520 & 502 & 457 & 493 & 482 & 612 & 418 & $402 *$ \\
\hline 2 & Sum of (1) (T) & \multicolumn{3}{|c|}{1432} & \multicolumn{3}{|c|}{1432} & \multicolumn{3}{|c|}{1432} & \multicolumn{3}{|c|}{1432} \\
\hline 3 & (Level sum)2 & 119716 & 243049 & 351649 & 168100 & 270400 & 252004 & 208849 & 243049 & 232324 & 374544 & 174724 & 161604 \\
\hline 4 & Sum of (3) & \multicolumn{3}{|c|}{714414} & \multicolumn{3}{|c|}{690504} & \multicolumn{3}{|c|}{684222} & \multicolumn{3}{|c|}{710872} \\
\hline 5 & $(4) / 3$ & \multicolumn{3}{|c|}{$2 ; 38 ; 138$} & \multicolumn{3}{|c|}{230168} & \multicolumn{3}{|c|}{228074} & \multicolumn{3}{|c|}{236957,33} \\
\hline 6 & C.T. $=(\mathrm{T}) 2 / 9$ & \multicolumn{3}{|c|}{$2 ; 27 ; 847,11$} & \multicolumn{3}{|c|}{227847,11} & \multicolumn{3}{|c|}{227847,11} & \multicolumn{3}{|c|}{227847,11} \\
\hline 7 & $(5)-(6)$ & \multicolumn{3}{|c|}{10291} & \multicolumn{3}{|c|}{2321} & \multicolumn{3}{|c|}{227} & \multicolumn{3}{|c|}{9110} \\
\hline
\end{tabular}

(* Indicates the optimum level, hence optimum is $\mathrm{A}_{0} \mathrm{~B}_{0} \mathrm{C}_{2}$ ) 
Table 6 Computation of variance

\begin{tabular}{|c|c|c|c|c|c|}
\hline Factor $\downarrow$ & S.O.S & D.O.F & V (M.S.) & F0 (0,05) \\
\hline A (Cutting speed) & 10291 & 2 & 5145 & 45,33 \\
\hline B (Pulse width) & 2321 & 2 & 1160 & 19 \\
\hline C (Pulse frequency) & 9110 & 2 & 4555 & 19 \\
\hline E (Error) & 227 & 2 & 113 & 40,13 \\
\hline T (Total) & 21949 & 8 & - & - & - \\
\hline
\end{tabular}

Table 7 Percentage contribution of various factors

\begin{tabular}{|c|c|}
\hline Factor & $\begin{array}{c}\text { \% contribution to variation in } \\
R a \text { value }\end{array}$ \\
\hline Cutting speed (A) & 45,85 \\
\hline Pulse width (B) & 9,54 \\
\hline Pulse frequency (C) & 40,47 \\
\hline Error (e) & 2,07 \\
\hline
\end{tabular}

\section{$5 \quad \mathrm{~S} / \mathrm{N}$ ratio analysis}

For the less good problem as this one (1):

$$
S / N=-10 \log _{10}\left(\frac{1}{n} \sum y_{i}^{2}\right)
$$

The $\mathrm{S} / \mathrm{N}$ analysis of the orthogonal array (Tabs. 3, 4) has indicated the optimum combination is $\mathrm{A} 0 \mathrm{~B} 0 \mathrm{C} 2$ that is cutting speed $v=1 \mathrm{~mm} / \mathrm{s}$, pulse width $1,5 \mathrm{~ms}$, pulse frequency or repetition rate $20 \mathrm{~Hz}$ which was not among the tested conditions \& was carried out later. It resulted in $R a=100 \mu \mathrm{m}$, which is the best of the tested conditions hence; it confirms the prediction of $\mathrm{S} / \mathrm{N}$ analysis. The values (Tab. 4) indicate the variation over mean value of $\mathrm{S} / \mathrm{N}$ ratio $(-43,91457)$. The variance analysis (Tabs. 5,6$)$ indicates that the optimum parametric combination is A0B0C2 that is the same as indicated by the $\mathrm{S} / \mathrm{N}$ analysis and has been confirmed experimentally. The analysis indicates that the cutting speed and pulse frequency are the most influential factors and contribute $45,85 \%$ \& 40,47\% respectively (Tab. 7), (Fig. 3).

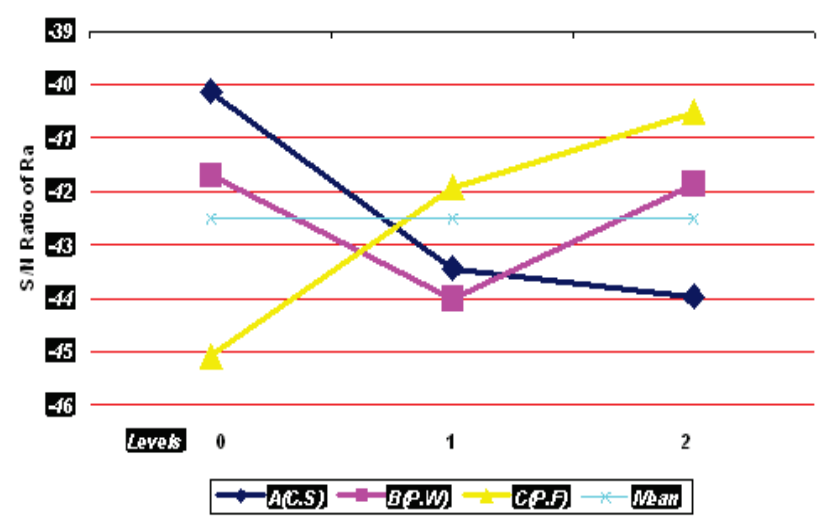

Figure 3 Effects of control factors on $R a$ value

\section{Conclusion}

Laser machining process is one of the most important non-traditional machining processes that has an ability to cut a wide range of materials ranging from mild steel (MS) to ceramics \& diamond with great precision. The process of Laser Cutting is controlled by three parameters laser pulse frequency (pulse repetition rate), laser pulse width and cutting speed. These factors have their particular effect as well as combined effect on the surface finish obtained. Earlier works have made it clear that apart from the effects of these three parameters alone, it is only laser pulse width and cutting speed which have a combined effect. To the best of our knowledge there has been no work in the direction of determining the amount of effect by these parameters.

The $\mathrm{S} / \mathrm{N}$ analysis and the variance analysis (Tabs. 4, 5 , 6) make it clear that the cutting speed \& pulse repetition rate are the most influencing factors in controlling surface roughness and the optimum parametric combination of selected parameters (control factors) for the given experiment is cutting speed $1 \mathrm{~mm} / \mathrm{s}$, pulse repetition rate $20 \mathrm{~Hz}$, pulse width 1,5 ms. The interaction between the three selected control factors is nonsynergetic. Surface finish deteriorates with increase in the value of cutting speed from $1 \mathrm{~mm} / \mathrm{sec}$ to $3 \mathrm{~mm} / \mathrm{s}$. Surface finish ( $R a$ value) improves as pulse frequency is increased from 10 to $15 \mathrm{~Hz}$ but remains stable when pulse frequency is further increased.

\section{References}

[1] Krajcarz, D. Comparison Metal Water Jet Cutting with Laser and Plasma Cutting. // Procedia Engineering. 69, (2014), pp. 838-843. DOI: 10.1016/j.proeng.2014.03.061

[2] Equbal, A.; Sood, A. M. Electrical Discharge Machining: An Overview on Various Areas of Research //Journal of Manufacturing and Industrial Engineering. 13, 1-2(2014), pp. 1-6. DOI: 10.12776/mie.v13i1-2.339

[3] Malhotra, N. Optimization of multiple quality characteristics of EDM process for MRR and TWR using utility concept. // Advances in Production Engineering \& Management. 8, 4(2013), pp. 219-230. DOI: 10.14743/apem2013.4.169

[4] Folkes, J. Waterjet -An innovative tool for manufacturing. // Journal of Materials Processing Technology. 209(2009), pp. 6181-6189. DOI: 10.1016/j.jmatprotec.2009.05.025

[5] Kulecki, M. K. Processes and apparatus developments in industrial waterjet applications // International Journal of Machine Tools and Manufacture. 42, (2002), pp. 1297-1306. DOI: 10.1016/S0890-6955(02)00069-X

[6] Cárach, J. et al. Tangential turning of Incoloy alloy 925 using abrasive water jet technology // International Journal of Advanced Manufacturing Technology. 82, 9-12(2016), pp. 1747-1752. DOI: 10.1007/s00170-015-7489-0

[7] Kim, S.; Kim M. Evaluation of cutting characterisation in plasma cutting of thick steel ship plates. // International Journal of Precision Engineering and Manufacturing. 14, 9(2013), pp. 1571-1575. DOI: 10.1007/s12541-013-0212-x

[8] Iosub, A.; Nagit, G.; Negoescu, F. Plasma Cutting of Composite Materials // Int J Mater Form (2008) 1(Suppl 1): 1347. DOI: $10.1007 / \mathrm{s} 12289-008-0113-1$

[9] Petru, J.; Zlamal, T.; Cep, R. et al. Influence of cutting parameters on heat-affected zone after laser cutting // Tehnicki Vjesnik-Technical Gazette. 20, 2(2013), pp. 225230.

[10] Molian, R.; Shrotriya, P.; Molian, P. Thermal stress fracture mode of $\mathrm{CO}_{2}$ laser cutting of aluminum nitride // 
International Journal of Advanced Manufacturing Technology. 7-8(2008), pp. 725-733. DOl: 10.1007/s00170007-1270-y

[11] Pleterski, M.; Muhic, T.; Klobcar, D. et al. Microstructural evolution of a cold work tool steel after pulsed laser remelting // Metalurgija. 51, 1(2012), pp. 13-16.

[12] Yi, P.; Liu, Y. C.; Shi, Y. J. et al. Investigation on the process of laser surface melting using two sequential scans. // International Journal of Advanced Manufacturing Technology. 1-4(2001), pp. 225-233.

[13] Pandey, A. R.; Dubey, A. K. Taguchi based fuzzy logic optimization of multiple quality characteristics in laser cutting of Duralumin sheet. // Optics and Lasers in Engineering. 50, 3(2012), pp. 328-335. DOl: 10.1016/j.optlaseng.2011.11.005

[14] Kardas, O. O.; Keles, O.; Akhtar, S.; Zilbas, B. S. Laser cutting of rectangular geometry in 2024 aluminum alloy: Thermal stress analysis. // Optics \& Laser Technology. 64(2014), pp. 274-256. DOI: 10.1016/j.optlastec.2014.05.029

[15] Sharma, A.; Yadava, V. Modelling and optimization of cut quality during pulsed Nd:YAG laser cutting of thin Al-alloy sheet for curved profile. // Optics and Lasers in Engineering. 51, 1(2013), pp. 77-88. DOI: 10.1016/j.optlaseng.2012.07.012

[16] Cukor, G.; Jurković, Z.; Sekulić, M. Rotatable central composite design of experiments versus Taguchi method in the optimization of turning. // Metalurgija. 50, 1 (2011), pp. $17-20$

[17] Jurkovic, Z.; Cukor, G.; Andrejcak, I. Improving the surface roughness at longitudinal turning using the different optimization methods. // Tehnicki Vjesnik-Technical Gazette. 17, 4 (2010), pp. 397-402.

[18] Sahin, Y.; Riza Motorcu, A. Surface Roughness Model for Machining Mild Steel with Coated Carbide Tool. // Materials \& Design. 26 (2005), pp. 321-326. DOl: 10.1016/j.matdes.2004.06.015

[19] Krolczyk, G.; Gajek, M.; Legutko, S. Predicting the tool life in the dry machining of duplex stainless steel. // Eksploatacja i Niezawodnosc - Maintenance and Reliability. 15, 1 (2013), pp. 62-65.

[20] Tam, S. C.; Lim E. N.; Quek, K. Y. Application of Taguchi methods in the optimization of the laser-cutting process // Journal of Materials Processing Technology. 29, 1-3(2008), pp. 63-74.

[21] Mital, A.; Mehta, M. Surface finish prediction models for fine turning. // International Journal of Production Research. 26, 12(1998), pp. 1861-1876. DOl: 10.1080/00207548808948001

[22] Kopac, J.; Bahor, M.; Sokovic, M. Optimal machining parameters for achieving the desired surface roughness in fine turning cold pre-formed steel work processing. // International Journal of Machine Tools and Manufacture. 42 (2002), pp. 707-716. DOI: 10.1016/S0890-6955(01)00163-8

[23] Puh, F.; Segota, T.; Jurkovic, Z. Optimization of hard turning process parameters with PCBN tool based on the Taguchi method // Tehnicki Vjesnik-Technical Gazette. 19, 2(2012), pp. 415-419

[24] Markovic, D.; Petrovic, G.; Cojbasic, Z. et al. A comparative analysis of metaheuristic maintenance optimization of refuse collection vehicles using the Taguchi experimental design. // Transactions of FAMENA. 36, 4(2012), pp. 25-38

[25] Want, Y. C.; Chen, C. H.; Lee, B. Y. The design model of mirco end-mills made by using the finite element method. // Transactions of FAMENA. 36, 2(2012), pp. 41-50

[26] Sharma, V. et al. Multi response optimization of process parameters based on Taguchi-Fuzzy model for coal cutting by water jet technology. // International Journal of Advanced Manufacturing Technology. 56, 9-12(2011), pp. 1747-1752. DOI: 10.1007/s00170-011-3258-x

[27] Mitra, N. S.; Doloi, B.; Bhattacharyya, B. Predictive analysis of criterial yield during travelling wire electrochemical discharge machining of Hylam based composites. // Advances in Production Engineering \& Management. 10, 2(2015), pp. 73-86. DOI: 10.14743/apem2015.2.193

[28] Vijay Sekar K. S.; Pradeep Kumar M. Optimising Flow Stress Input for Machining Simulations Using Taguchi Methodology. // International Journal of Simulation Modelling. 11, 1(2012), pp. 17-28. DOl: 10.2507/IJSIMM11(1)2.195

[29] Taguchi, G.; Chowdhurz, S.; Wo, Y. Taguchi's Quality Engineering Handbook. 2004, pp. 1696. DOl: 10.1002/9780470258354

\section{Authors' addresses}

\section{Vinay Sharma}

Department of Production Engineering,

Birla Institute of Technology,

Mesra, Ranchi, India - 835215

Somnath Chattopadhyaya
Department of ME \& MME,

IndianInstitute of Technology (Indian School of Mines), Dhanbad, India - 835215

\section{Sergej Hloch}

Faculty of Manufacturing Technologies of Technical Universtity of Košice with a seat in Prešov Bayerova 1, 08001 Prešov

Slovak Republic

Institute of Geonicsof the CAS, v. v. i.

Studentska 1768 ,

Ostrava-Poruba, 70800

Czech Republic 